\title{
Co-digestion of spoiled maize silage with cattle manure
}

\author{
Ali AYBEK ${ }^{1}$ (D), Mehmet SOLAK ${ }^{2}$ (i), Kamil EKINCI ${ }^{3}$ (D) \\ Kahramanmaras Sutcu Imam University, Faculty of Agriculture, Biosystems Engineering Department, 46100, Kahramanmaras, Turkey \\ ${ }^{2}$ Siirt University, Faculty of Agriculture, Department of Biosystems Engineering, Siirt, Turkey \\ ${ }^{3}$ Isparta University of Applied Sciences, Faculty of Agricultural Sciences and Technologies, Department of Agricultural Machinery and Technologies \\ Engineering, 32260, Isparta, Turkey
}

Corresponding author: A. Aybek, e-mail: aaybek@ksu.edu.tr

Author(s) e-mail: solakmehmet@yandex.com, kamilekinci@isparta.edu.tr

\section{ARTICLE INFO}

Received: March 5, 2021

Received in revised form: October 4, 2021

Accepted: October 6, 2021

\section{Keywords:}

Spoiled maize silage

Cattle manure

Co-digestion

Biogas

HBT

\begin{abstract}
In this study, spoiled maize silage (SMS) and cattle manure were co-digested at five different mixtures by the Hohenheim Batch Yield Test unit under mesophilic conditions to explore biogas production possibilities of these wastes together. The mixtures were $100 \%$ cattle manure, $100 \%$ SMS, $85 \%$ cattle manure $+15 \%$ SMS, $70 \%$ cattle manure $+30 \%$ SMS, and $55 \%$ cattle manure $+45 \%$ SMS. Chemical properties of raw materials and mixtures, including crude fat, dry matter, organic matter, and acid detergent fiber (ADF) contents were determined. As the amount of SMS in the mixtures increased, biogas and methane production increased. The highest cumulative specific biogas and methane production were determined for $100 \%$ SMS as 0.62 $\mathrm{Nm}^{3} \mathrm{~kg}^{-1}$ organic matter $(\mathrm{OM})$ and $0.31 \mathrm{Nm}^{3} \mathrm{~kg}^{-1} \mathrm{OM}$, respectively, where $\mathrm{Nm}^{3}$ is the volume of biogas under normal conditions. Methane content of the mixture containing SMS (49.99\% to $51.87 \%$ ) was higher than that of cattle manure only $(44.01 \%)$. Furthermore, the mixtures which had lower ADF content yielded more methane and biogas. In conclusion, the efficiency of biogas and methane production can be increased by applying the co-digestion technique.
\end{abstract}

\section{Introduction}

An increase in the world population led to increased energy demand. One of the most vital development indicators of the countries is energy consumption per capita (Ergüneş et al. 2009; Ulusoy et al. 2009; Aybek and Üçok 2017). Fossil fuels such as petroleum, natural gas, and coal are used to meet the energy demand in the World (Onurbaş Avcıoğlu et al. 2011; Yılmaz 2012; IEA 2015). Renewable energy sources are alternatives to fossil energy sources provided by nature. Renewable energy originating from rivers, wind, geothermal energy, biomass, and sun are the energy sources that do not cause environmental pollution (Temiz and Gökmen 2010). Biogas technology is at the forefront of renewable energy production. Biogas is a flammable gas originating from the anaerobic digestion of organic substances containing carbon dioxide, methane, and other small amounts of trace gasses.

Biogas technology with environmental and economic benefits is crucial (Angelidaki and Ahring 1993). Biogas production enables organic wastes to be used both as organic fertilizers and to gain an economic value by producing energy (Üçgül and Akgül 2010). Currently, many studies have been carried out determining the biogas potential of various organic wastes. Determination of biogas potentials of organic wastes is essential for the design and economics of biogas plants (Korkmaz et al. 2012). Biogas production from organic materials with high biomethane potential can be feasible (Mittweg et al. 2012a). Significant amounts of energy can be recovered from agricultural residues/wastes in Turkey for biogas production. The utilization of organic wastes in biogas production provides an economic contribution by generating energy and eliminating the adverse effects of these wastes on air, water, and soil.

Furthermore, the digestate of the anaerobic process can be applied to agricultural land as an organic soil conditioner (Yaldiz 2000). Since there is a significant potential for organic wastes in Turkey, the determination of the biogas potential of these wastes and research on the possibilities of usage of biogas as renewable energy sources lead to a robust database (Aybek et al. 2015). Wastes from plant and animal production in agriculture, which have high potential in rural areas in Turkey, are the most critical materials for biogas production.

Biogas production from energy crops is widespread around the world. Of many products utilized in biogas plants, maize silage holds a key position for biogas production due to its high methane yield and chemical composition (Oslaj et al. 2010). In various regions of the world, silage maize (Zea mays L.) is commonly cultivated. The crop offers a very consistent production over a wide range of climatic and agronomic circumstances and a high energy content and strong ensiling properties. Furthermore, maize silage in dairy cows' grass or grass silage-based diets enhances feed intake, milk production, and milk protein content (Phipps et al. 1995; Khan et al. 2012). Storage of biomass is the ultimate problem; agricultural products tend to rot quickly when not properly stored. In both energy production and animal feeding, the quality of silage and the reduction of dry matter losses are vital factors to consider (Borreani and Tabacco 2010a; Borreani and Tabacco 2010b). 
Microbial oxidation of silage fermentation products, such as lactic acid and residual water-soluble carbon to carbon dioxide and water is induced by oxygen penetration into the silo. There is a rise in temperature above ambient, as well as increased mass and nutritional losses (Wilkinson and Davies 2013). Aerobic deterioration - rot - is caused by failure to follow the technological discipline of silage preparation or storage or the use of inappropriate feed. With access to air, this deterioration rots silage through biological reactions. The unexpected air entry into silages creates butyric, acetic, or formic acids, rendering silage useless. Depending on the density and porosity of the plant material and the rate of silage removal, silos are opened, and the air is allowed to enter the silage. This results in the proliferation of unwanted aerobic microorganisms, such as yeasts and molds, which were previously present in the silage, as well as a rise in pH (Driehuis and Elferink 2000).

There have been many studies carried out on mono and codigestion of maize silage. Research consisting of both laboratory and full scale investigated the possibilities of using maize silage for biogas production. It showed that maize silage is a suitable substrate for anaerobic digestion and biogas production.The observed specific methane generation for long-term maize silage processing in a mixed laboratory anaerobic reactor was 0.316 $\mathrm{Nm}^{3} \mathrm{~kg}^{-1}$ of VS (volatile solids) (Hutňan 2016). According to a study by Hutňan et al. (2010), specific biogas generation from maize silage reached $0.66 \mathrm{~m}^{3} \mathrm{~kg}^{-1} \mathrm{VS}$. Another study found that co-digestion of maize silage with chicken manure in 5-liter digesters led to $0.31 \mathrm{~L} \mathrm{CH}_{4} \mathrm{~g}^{-1}$ VS specific methane output (Sun et al. 2016). When comparing sugar beet and maize silage, researchers discovered that maize silage had a slightly lower anaerobic conversion rate than sugar beet silage due to a large number of complex chemicals (Klang et al. 2015).

The HBT (Patent No. 10227685, 20.01.2005) is a highefficiency discontinuous laboratory batch method (Heffrich et al. 2003) for determining the biogas and methane production potential of varying substrates according to the VDI Guideline 4630 (VDI-Richtlinie 4630 2006). An advantage of the HBT over the $2 \mathrm{~L}$ batch approach is the higher performance due to the significant number of digesters per batch method to determine biogas and methane production potential. Additionally, only small quantities of the substrate to be tested are needed for the analyses, making the HBT applicable for plant breeding approaches where only small amounts of the plant material are available (Mittweg et al. 2012b).

The objective of this study was to determine the biogas production efficiencies of the mixtures obtained from cattle manure and SMS by using the Hohenheim Batch Yield Test (HBT) The specific aim of this study was to determine specific biogas production as a function of mixtures of cattle manure and SMS.

\section{Materials and Methods}

\subsection{Material preparation}

Cattle manure and SMS were obtained from livestock farms in the Eastern Mediterranean Region. The wastes were dried at room temperature for three weeks. Wastes were ground in $1 \mathrm{~mm}$ size according to the standards related (VDI 4630 2006) using an industrial type grinder. The main characteristics of the raw materials (cattle manure and SMS) are reported in Table 1. The moisture contents of the samples were determined as $9.26 \%$ and $6.44 \%$ (wet basis) for cattle manure and SMS, respectively. Cattle manure had an organic matter (OM) of $90.79 \%$, while MS had an organic matter of $95.02 \%$. Cattle manure and SMS had a crude fat content of 2.30 and $2.33 \%$, respectively. Cattle manure was rich in Acid Detergent Fiber (ADF) of 60.19\%. Values reported are on a dry weight basis except for moisture content on a wet weight basis. Compositions of feeds at the beginning of the experiment are given in Table 1 . The number of replication for each mixture was 3 .

\subsection{Preparation of inoculum}

Inoculum, which is a mixture of liquid + solid phase, was obtained from Gaziantep Water and Sewerage Administration (GASKI) central wastewater treatment plant. The four-layered cheesecloth was used to filter, mixed with a 1:2 ratio of buffer solution. Buffer solution; $500 \mathrm{~mL}$ of distilled purified water was formed from $0.1 \mathrm{~mL}$ of solution $\mathrm{A}, 200 \mathrm{~mL}$ of solution $\mathrm{B}, 200$ $\mathrm{mL}$ of solution $\mathrm{C}, 1 \mathrm{~mL}$ of resazurin $\left(0.1 \%, \mathrm{w} \mathrm{v}^{-1}\right)$ solution $\mathrm{C}$, and $40 \mathrm{~mL}$ of solution E. Solution A was mixed with $13.2 \mathrm{~g}$ $\mathrm{CuCl}_{22} \mathrm{H}_{2} \mathrm{O}, 10.0 \mathrm{~g} \mathrm{MnCl}_{24} \mathrm{H}_{2} \mathrm{O}, 1.0 \mathrm{~g} \mathrm{CoCl}_{26} \mathrm{H}_{2} \mathrm{O}$, and $8.0 \mathrm{~g}$ $\mathrm{FeCl}_{2} \mathrm{H}_{2} \mathrm{O}$ in distilled water. Solution $\mathrm{B}$ was dissolved in $35 \mathrm{~g}$ of $\mathrm{NaHCO}_{3}$ and $4 \mathrm{~g}$ of $\mathrm{NH}_{4} \mathrm{HCO}_{3}$ in pure water to complete $100 \mathrm{~mL}$. Solution $\mathrm{C}$ was dissolved in $5.7 \mathrm{~g}$ of $\mathrm{Na}_{2} \mathrm{HPO}_{4}, 6.2 \mathrm{~g}$ of $\mathrm{KH}_{2} \mathrm{PO}_{4}$, $0.6 \mathrm{~g}$ of $\mathrm{MgSO}_{47} \mathrm{H}_{2} \mathrm{O}$ in pure water, and $1000 \mathrm{~mL}$ was completed. Solution D was dissolved in $0.5 \mathrm{~g}$ of resazurin pure water to complete $100 \mathrm{ml}$. Solution E consists of $95 \mathrm{~mL}$ of distilled water, four $\mathrm{mL}$ of $1 \mathrm{~N} \mathrm{NaOH}$, and $625 \mathrm{mg} \mathrm{Na} \mathrm{S}_{9} \mathrm{H}_{2} \mathrm{O}$.

\subsection{Biogas and methane measurements}

The biogas experiment was carried out using the HBT method (Heffrich and Oechsner 2003). In this study, the prepared samples were placed into $100 \mathrm{~mL}$ glass syringes located in the incubator. Likewise, three inoculum syringes, each containing 30 $\mathrm{mL}$ of inoculum for control group samples were also placed in the sections of the incubator. The syringes were placed horizontally into the incubator at $37^{\circ} \mathrm{C}$ after the inoculum was placed. The methane measurement system was used to determine the methane content before the incubator was calibrated with

Table 1. Chemical properties of materials

\begin{tabular}{|c|c|c|c|c|c|c|c|}
\hline \multirow{2}{*}{ Mixes } & \multicolumn{2}{|c|}{ Materials in mixtures } & \multirow{2}{*}{$\begin{array}{c}\text { Moisture content } \\
\text { (\%) }\end{array}$} & \multirow{2}{*}{$\begin{array}{c}\text { Dry matter } \\
(\%)\end{array}$} & \multirow{2}{*}{$\begin{array}{c}\text { Organic matter } \\
(\%)\end{array}$} & \multirow{2}{*}{$\begin{array}{c}\text { Crude fat } \\
(\%)\end{array}$} & \multirow{2}{*}{$\begin{array}{l}\mathrm{ADF} \\
(\%)\end{array}$} \\
\hline & Cattle manure $(\%)$ & SMS (\%) & & & & & \\
\hline Mixture-1 & 100 & - & 9.26 & 90.74 & 90.79 & 2.30 & 60.19 \\
\hline Mixture-2 & - & 100 & 6.44 & 93.56 & 95.02 & 2.33 & 22.74 \\
\hline Mixture-3 & 85 & 15 & 8.77 & 91.23 & 94.45 & 2.13 & 24.71 \\
\hline Mixture-4 & 70 & 30 & 8.69 & 91.31 & 93.13 & 2.25 & 26.47 \\
\hline Mixture-5 & 55 & 45 & 7.84 & 92.16 & 92.30 & 2.43 & 26.01 \\
\hline
\end{tabular}


a calibration tube (60.5\% CH4) (S-AGM plus 1010 sensor). The purpose of the calibration was to verify that the measured gas was at standard conditions $\left(0^{\circ} \mathrm{C}\right.$ and $\left.1013 \mathrm{hPa}\right)$. Experiments lasted for 35 days. Measurements were made every six hours for the first six days, eight and twelve hours later the subsequent days, and the methane efficiency in each sample was determined. While Equation (1) was used to calculate the normal volume of the produced gas in the glass syringes prepared for each sample of the materials studied, Equation (2) was used to determine the methane content of the formed biogas. Equation (3) was used to calculate cumulative methane over time (VDI 4630 2006).

$$
V_{0}^{n}=V\left(\frac{\left(P-P_{w}\right)\left(T_{0}\right)}{\left(P_{0}\right)(T)}\right)
$$

Where, $V_{0}^{n}$ is the volume of gas under normal conditions $(\mathrm{mLN}), \mathrm{V}$ is the volume of gas read $(\mathrm{mL}), \mathrm{P}$ is the air pressure at the time of reading $(\mathrm{hPa}), \mathrm{P}_{\mathrm{w}}$ is the steam temperature of the water in the outside $(\mathrm{hPa}), \mathrm{T}_{0}$ is the normal temperature $\left(273^{\circ} \mathrm{K}\right), \mathrm{P}_{0}$ is the normal pressure $(1013 \mathrm{hPa})$, and $\mathrm{T}$ is the temperature of the gas which has undergone digestion in the outside $\left({ }^{\circ} \mathrm{K}\right)$.

$$
C_{C H_{4}}^{n}=C_{C H_{4}}^{f}\left(\frac{P}{\left(P-P_{w}\right)}\right)
$$

Where $C_{\mathrm{CH}_{4}}^{n}$ is the volumetric methane content in dry biogas (\%), $\mathrm{C}_{\mathrm{CH}_{4}}^{f}$ is the volumetric methane content in moist biogas (\%).

$$
M_{C H_{4}}(t)=M_{C_{4}}(0)+\int_{t_{1}}^{t_{2}} M_{C_{4}}(t) d t
$$

Where $M_{\mathrm{CH}_{4}}(t)$ is the cumulative methane production $\left(\mathrm{Nm}^{3}\right.$ $\mathrm{CH}_{4} \mathrm{~kg}^{-1}(\mathrm{OM}), M_{\mathrm{CH}_{4}}(0)$ is methane production when $\mathrm{t}=0\left(\mathrm{Nm}^{3}\right.$ $\mathrm{CH}_{4} \mathrm{~kg}^{-1} \mathrm{OM}$ ), and $\mathrm{t}_{2}-\mathrm{t}_{1}$ is time between two measurements ( $\mathrm{min}$ ).

\subsection{Chemical analysis}

The crude protein, crude oil, dry matter, OM, and ADF contents of the samples in the study were determined. Crude protein analysis was performed by the Kjeldahl method and crude oil analysis by TS 6317 and Foss Soxtec method. The dry matter and OM analysis were determined according to VDI 4630 (2006), standard VDI 4630 (2006), and AOAC (1990). ADF analysis were conducted by (Van Soest et al. 1991).

\subsection{Evaluation of data}

The mean and standard deviation values, statistical analyzes, and variance analyzes of the measurements made in three replicates were determined, and the obtained values were interpreted by transferring them into the figures and tables.

\section{Results and Discussion}

\subsection{Chemical properties of materials}

Results of initial chemical analysis for Mixture-1 through Mixture-5 are given in Table 1 . While the highest OM content was measured for SMS (95.02\%), the lowest was cattle manure at $90.79 \%$. As the proportion of SMS in the mixture increased, the DM also increased (Table 1). The highest and the lowest ADF content were determined for cattle manure and SMS as $60.19 \%$ and $22.74 \%$, respectively. The crude oil content of mixes, an essential parameter for biogas production, ranged from 2.13 to $2.43 \%$.

\subsection{Biogas and methane production values of materials}

The cumulative specific methane production of mixtures and inoculum as a function of time is shown in Figure 1. The results of cumulative specific methane and biogas productions are shown in Table 2. The results of variance analysis of methane production, biogas production, and methane content are given in Table 3.

According to the test standards, cumulative specific methane production from the inoculum should be 0-0.1 $\mathrm{Nm}^{3} \mathrm{~kg}^{-1}$ organic matter (OM) (VDI 4630 2006). In this study, the cumulative specific methane production from the inoculum was $0.09 \mathrm{Nm}^{3} \mathrm{~kg}^{-1} \mathrm{OM}^{-1}$. The cumulative methane production occurred on the first day, increased gradually, and attained the maximum value at days 30-35 (Figure 1). As the proportion of SMS in mixtures increased, cumulative specific methane production increased. The results revealed that the highest cumulative specific biogas production value was determined for Mixture-2 (SMS) as $0.62 \mathrm{Nm}^{3} \mathrm{~kg}^{-1} \mathrm{OM}$. It was followed by

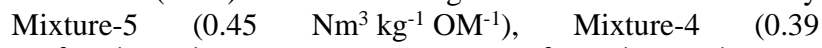
$\left.\mathrm{Nm}^{3} \mathrm{~kg}^{-1} \mathrm{OM}^{-1}\right), \quad$ Mixture-3 $\left(0.32 \quad \mathrm{Nm}^{3} \quad \mathrm{~kg}^{-1} \quad \mathrm{OM}^{-1}\right)$, and Mixture-1 (0.27 $\mathrm{Nm}^{3} \mathrm{~kg}^{-1} \mathrm{OM}^{-1}$ ) (Table 2). (Arıcı and Koçar 2015) conducted on co-digestion of a mixture of $50 \%$ cattle manure $+50 \%$ maize silage in the mesophilic conditions $\left(37^{\circ} \mathrm{C}\right)$ showed that biogas production $0.415 \mathrm{Nm}^{3} \mathrm{~kg}^{-1} \mathrm{OM}^{-1}$. A similar study on co-digestion of the mixture containing $75 \%$ cattle manure and $25 \%$ maize silage in the $37^{\circ} \mathrm{C}$ conditions resulted in $0.445 \mathrm{Nm}^{3} \mathrm{~kg}^{-1} \mathrm{OM}^{-1}$ biogas production (Ayhan 2013). As for the cumulative methane production of the mixture, the highest cumulative methane production was measured for Mixture-2 $\left(0.31 \mathrm{Nm}^{3} \mathrm{~kg}^{-1} \mathrm{OM}^{-1}\right)$. It is followed by Mixture-5 $(0.22$ $\left.\mathrm{Nm}^{3} \mathrm{~kg}^{-1} \mathrm{OM}^{-1}\right)$, Mixture-4 $\left(0.19 \mathrm{Nm}^{3} \mathrm{~kg}^{-1} \mathrm{OM}^{-1}\right)$, Mixture-3 $\left(0.15 \mathrm{Nm}^{3} \mathrm{~kg}^{-1} \mathrm{OM}^{-1}\right)$, and Mixture-1 $\left(0.12 \mathrm{Nm}^{3} \mathrm{~kg}^{-1} \mathrm{OM}^{-1}\right)$ (Table 2). The results showed that the methane content in the biogas increased as the proportion of SMS in the mixture increased. Methane content from the mixture containing SMS ranged from $49.99 \%$ to $51.87 \%$, while Mixture-1 (cattle manure) yielded a methane content of $44.01 \%$ (Table 2). The methane, biogas production, and methane content of all the mixtures were statistically significant $(P \leq 0.05)$ (Table 3$)$.

Methane and biogas production varied based on the ADF content of mixtures. Chemical analysis of the mixture showed that the lowest and the highest ADF content were determined for Mixture-2 (SMS) and Mixture-1 (cattle manure) as 22.74 and $60.19 \%$, respectively. It was found that there was a negative correlation between the amount of ADF and methane and biogas production. Similarly, Jimenez et al. (1990) reported that Pearson's coefficient correlated the hemicellulose content in a significant and positive way for biogas production. The negative and statistically significant relationship was established for biogas production and $\mathrm{ADF}$ parameters. 


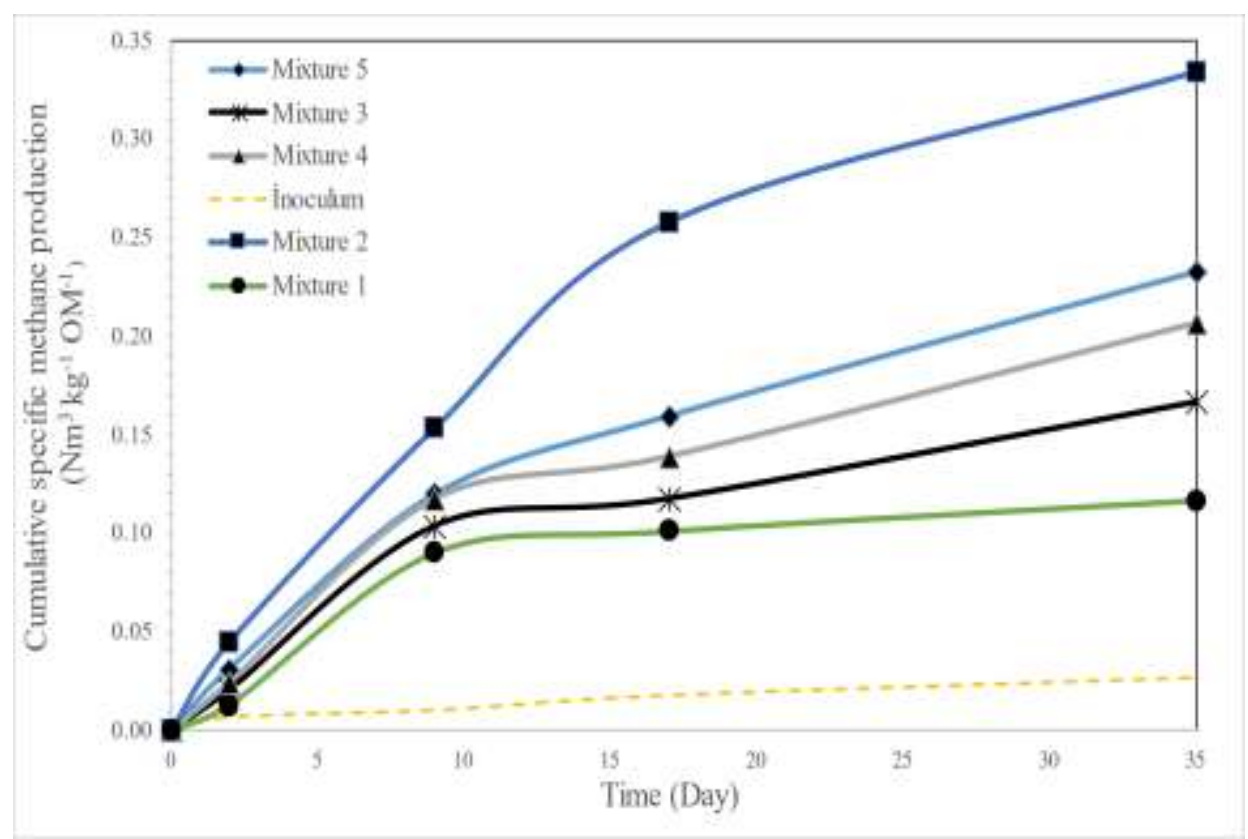

Figure 1. Average cumulative methane production of mixtures over time.

Table 2. The cumulative specific methane, biogas production and methane content in the mixes

\begin{tabular}{|c|c|c|c|c|c|c|c|c|c|}
\hline \multirow{3}{*}{ Mixes } & \multirow{2}{*}{\multicolumn{4}{|c|}{$\begin{array}{c}\text { Cumulative specific biogas production } \\
\qquad \mathrm{Nm}^{3} \mathrm{~kg}^{-1} \mathrm{OM}^{-1} \\
\text { Measurements }\end{array}$}} & \multirow{2}{*}{\multicolumn{4}{|c|}{$\begin{array}{l}\text { Cumulative specific methane production } \\
\qquad \mathrm{Nm}^{3} \mathrm{~kg}^{-1} \mathrm{OM}^{-1} \\
\text { Measurements }\end{array}$}} & \multirow{3}{*}{$\begin{array}{c}\text { Methane } \\
\text { content }(\%)\end{array}$} \\
\hline & & & & & & & & & \\
\hline & 1. & 2. & 3. & Avr. \pm Stdv & 1. & 2. & 3. & Avr. \pm Stdv & \\
\hline Mixture-1 & 0.25 & 0.31 & 0.24 & $0.27 \pm 0.017 \mathrm{~d}$ & 0.10 & 0.14 & 0.10 & $0.12 \pm 0.009 \mathrm{~d}$ & $44.01 \mathrm{~b}$ \\
\hline Mixture-2 & 0.69 & 0.61 & 0.56 & $0.62 \pm 0.029 \mathrm{a}$ & 0.35 & 0.30 & 0.28 & $0.31 \pm 0.017 \mathrm{a}$ & $49.99 \mathrm{a}$ \\
\hline Mixture-3 & 0.35 & 0.31 & 0.29 & $0.32 \pm 0.013 \mathrm{~cd}$ & 0.18 & 0.16 & 0.14 & $0.15 \pm 0.007 \mathrm{~cd}$ & $51.81 \mathrm{a}$ \\
\hline Mixture-4 & 0.39 & 0.41 & 0.38 & $0.39 \pm 0.015 \mathrm{bc}$ & 0.20 & 0.21 & 0.19 & $0.19 \pm 0.005 \mathrm{bc}$ & $51.87 \mathrm{a}$ \\
\hline Mixture-5 & 0.45 & 0.44 & 0.47 & $0.45 \pm 0.006 \mathrm{~b}$ & 0.22 & 0.23 & 0.24 & $0.22 \pm 0.003 \mathrm{~b}$ & $50.79 \mathrm{a}$ \\
\hline
\end{tabular}

$P \leq 0.05$; The differences between the cumulative specific methane, biogas productions and methane ratio averages in the biogas are indicated by different letters in the same column a, b, c, d, e.

Table 3. Analysis of variance of methane and biogas production in the mixes

\begin{tabular}{|c|c|c|c|c|c|c|c|}
\hline Biogas parameters & Source of variance & SD & SS & MS & F value & SEM & $\mathrm{P}$-value \\
\hline \multirow{3}{*}{$\begin{array}{l}\text { Methane production } \\
\left(\mathrm{Nm}^{3} \mathrm{~kg}^{-1} \mathrm{OM}^{-1}\right)\end{array}$} & Between groups & 4 & 0.063 & 0.016 & 30.040 & 1.466 & \multirow{3}{*}{$0.000^{* * *}$} \\
\hline & Inside groups & 10 & 0.005 & 0.001 & & 1.466 & \\
\hline & Total & 14 & 0.068 & & & 1.466 & \\
\hline \multirow{3}{*}{$\begin{array}{l}\text { Biogas production } \\
\left(\mathrm{Nm}^{3} \mathrm{~kg}^{-1} \mathrm{OM}^{-1}\right)\end{array}$} & Between groups & 4 & 0.225 & 0.056 & 37.349 & 0.0250 & \multirow{3}{*}{$0.000^{* * *}$} \\
\hline & Inside groups & 10 & 0.015 & 0.002 & & 0.0250 & \\
\hline & Total & 14 & 0.240 & & & 0.0250 & \\
\hline \multirow{3}{*}{$\begin{array}{l}\text { Methane } \\
\text { content }(\%)\end{array}$} & Between groups & 4 & 28.497 & 32.124 & 18.996 & 0.037 & \multirow{3}{*}{$0.000^{* * * *}$} \\
\hline & Inside groups & 10 & 16.911 & 1.691 & & 0.037 & \\
\hline & Total & 14 & 145.407 & & & 0.037 & \\
\hline
\end{tabular}
Standard Deviation, SS: Some of the Squares, MS: Mean Square, SEM: Standard Error of the Mean).

\section{Conclusions}

In this study, co-digestion of SMS and cattle manure using the HBT was performed at mesophilic conditions. Preparing The mixtures tested were $85 \%$ cattle manure $+15 \%$ SMS, $70 \%$ cattle manure $+30 \%$ SMS, $55 \%$ cattle manure $+45 \%$ SMS, $100 \%$ cattle manure, $100 \%$ SMS. As the proportion of SMS in mixtures increased, cumulative specific methane and biogas production increased. The highest cumulative specific biogas production value was determined for $100 \%$ SMS as $0.62 \mathrm{Nm}^{3} \mathrm{~kg}^{-1} \mathrm{OM}^{-1}$. The highest cumulative methane production was measured for
$100 \%$ SMS as $0.31 \mathrm{Nm}^{3} \mathrm{~kg}^{-1} \mathrm{OM}^{-1}$. Methane content from the mixture containing SMS ranged from $49.99 \%$ to $51.87 \%$, while cattle manure yielded a methane content of $44.01 \%$. Methane and biogas production changed based on the ADF content of mixtures.

In conclusion, the efficiency of biogas and methane production can be increased by applying the co-digestion technique of organic substances together. SMS and cattle manure can be used as a suitable source for biogas plants. 


\section{Acknowledgments}

We would like to thank Kahramanmaraş Sütçü İmam University Rectorate for the support under the coverage of Scientific Research Projects (Project Number: 2017/6-5) in this research.

\section{References}

Angelidaki I, Ahring BK (1993) Thermophilic anaerobic digestion of livestock waste: The effect of ammonia. Applied Microbiology Biotechnology 38: 560-564.

AOAC (1990) Official Methods of Analysis. 15th ed. Association of Official Analytical Chemists, Washington, DC. The US

Arıcı Ş, Koçar G (2015) Effect of adding maize silage as co-substrate for anaerobic animal manure digestion. International Journal of Green Energy 12(5): 453-460.

Aybek A, Üçok S, Bilgili ME, İspir MA (2015) Digital mapping and determination of biogas energy potential of usable animal manure and cereal straw wastes in turkey. Journal of Tekirdag Agricultural Faculty 12(3): 109-120.

Aybek A, Üçok S (2017) Determination and evaluation of biogas and methane productions of vegetable and fruit wastes with HBT method. International Journal of Agricultural and Biological Engineering 10(4): 207-215.

Ayhan AA (2013) Research on determination of biogas quantity from cattle manure and maize silage at different mixing ratio under mesophilic conditions. Ph.D. Thesis, Uludağ University, Bursa.

Borreani G, Tabacco E (2010a) The relationship of silage temperature with the microbiological status of the face of corn silage bunkers. Journal of Dairy Science 93(6): 2620-9.

Borreani G, Tabacco E (2010b) Use of new plastic stretch films with enhanced oxygen impermeability to wrap baled alfalfa silage. Transactions of the ASABE 53(2): 635-41.

Driehuis F, Elferink SO (2000) The impact of the quality of silage on animal health and food safety: A review. Veterinary Quarterly 22(4): 212-6.

Ergüneş G, Tarhan S, Yardım MH, Kasap A, Demir F, Önal I, Uçar T, Tekelioğlu O, Çalışır S, Yumak H, Yağcıŏglu A (2009) Farm Machinery. Nobel Science and Research Center, Publish No: 49, 544, Ankara, Turkey.

Heffrich D, Oechsner H (2003) Comparison of different laboratory techniques for the digestion of biomass. Landtechnik 9: 27-30.

Hutňan M, Špalková V, Bodík I, Kolesárová N, Lazor M. (2010) Biogas production from maize grains and maize silage. Polish Journal of Environmental Studies 19(2): 323-329.

Hutňan M (2016) Maize silage as substrate for biogas production. Advances in Silage Production and Utilization 16: 173-96.

IEA (2015) Key World Energy Statistics https://www.ourenergypolicy.org/wpcontent/uploads/2016/09/KeyWorld2016.pdf. Accessed 4 March 2021.

Jimenez S, Cartagena MC, Aree A (1990) Influence of lignin on the methanation of lignocellulosic waste. Biomass and Bioenergy 21: 43-54.

Khan NA, Tewoldebrhan TA, Zom RL, Cone JW, Hendriks WH (2012) Effect of corn silage harvest maturity and concentrate type on milk fatty acid composition of dairy cows. Journal of Dairy Science 95(3): 1472-83.

Klang J, Theuerl S, Szewzyk U, Huth M, Tölle R, Klocke M (2015) Dynamic variation of the microbial community structure during the long-time mono-fermentation of maize and sugar beet silage. Microbial biotechnology 8(5): 764-75.
Korkmaz Y, Aykanat S, Çil A (2012) Biogas and energy production from organic wastes. SAU Journal of Science and Letters 12: 489-497.

Mittweg G, Oechsner H, Lemmer A, Hanisch AR (2012a) Repeatability of a laboratory batch method to determine the specific biogas and methane yields. Engineering in Life Sciences 12(3): 270-278.

Mittweg G, Oechsner H, Hahn V, Lemmer A, Reinhardt-Hanisch A (2012b) Repeatability of a laboratory batch method to determine the specific biogas and methane yields. Engineering in Life Sciences 12(3): 270-278.

Oslaj M, Mursec B, Vindis P (2010) Biogas production from maize hybrids. Biomass and Bioenergy 34: 1538-1545.

Onurbaş Avcıŏlu A, Türker U, Demirel Atasoy Z, Koçtürk D (2011) Renewable energies of agricultural origin - biofuels. Nobel Academic Publishing Education Consultancy LLC, No: 72, Ankara, Turkey.

Phipps RH, Sutton JD, Jones BA (1995) Forage mixtures for dairy cows: The effect on dry-matter intake and milk production of incorporating either fermented or urea-treated whole-crop wheat, brewers' grains, fodder beet or maize silage into diets based on grass silage. Animal Science 61(3): 491-6.

Sun C, Cao W, Banks CJ, Heaven S, Liu R (2016) Biogas production from undiluted chicken manure and maize silage: a study of ammonia inhibition in high solids anaerobic digestion. Bioresource Technology 218: 1215-23.

Temiz D, Gökmen A (2010) The importance of renewable energy sources in Turkey. International Journal of Economics and Finance Studies 2(2): 23-30.

Ulusoy Y, Ulukardeşler AH, Ünal H, Alibaş K (2009) Analysis of biogas production in Turkey utilizing three different materials and two scenarios. African Journal of Agricultural Research 4(10): 996-1003.

Üçgül D, Akgül G (2010) Biomass Technology. YEKARUM Journal (1): 3-11.

Van Soest PJ, Robertson JB, Lewis BA (1991) Methods for dietary fiber neutral detergent fiber and nonstarch polysaccharides in relation to animal nutrition. Journal of Dairy Science 74: 3583-3597.

VDI 4630 (2006) Fermentation of organic material, characterisation of substrate, collection of material data, fermentation tests, VDI Gesellschaft Energietechnik.

VDI-Richtlinie 4630 (2006) Verg"arung organischer stoffe. VDIGesellschaft energietechnik, Dusseldorf, ICS 13.030.30; 27.190, pp. 59.

Wilkinson JM, Davies DR (2013) The aerobic stability of silage: Key findings and recent developments. Grass and Forage Science (1): 19.

Yaldız O (2000) Biogas Technology, Course Book. Akdeniz University Publications, Publication No: 78, pp. 181.

Y1lmaz M (2012) Turkey's energy potential of renewable energy and importance of the topic from the point of electric power generation. Ankara University Journal of Environmental Sciences 4(2): 33-54. 